\title{
An inventory of bryophytes on the summit of Pink Mountain (Peace River District, British Columbia, Canada)
}

\author{
Ernest T.Y. Wu ${ }^{1}$, DAniel P. Mosquin², and Robert D. GuY ${ }^{1, *}$ \\ ${ }^{1}$ Department of Forest and Conservation Sciences, Faculty of Forestry, University of British Columbia, \\ Forest Sciences Centre, 2424 Main Mall, Vancouver, BC V6T 1Z4, Canada \\ ${ }^{2}$ Botanical Garden and Centre for Plant Research, University of British Columbia, \\ 6804 SW Marine Drive, Vancouver, BC V6T 1Z4, Canada
}

\begin{abstract}
Aвstract.-The bryophyte diversity in northern British Columbia is insufficiently studied. We conducted a bryophyte survey in a $2.2-\mathrm{km}^{2}$ proposed ecological reserve at the summit of Pink Mountain in the Peace River District of northern British Columbia. Pink Mountain is at the southern periphery of the ranges of several arctic flora species as well as the northernmost reaches of other temperate flora species. The south summit of Pink Mountain has a high floristic diversity coincident with its limestone geology, which provides a more alkaline condition for plant growth than the north summit does. We documented 65 species, including 2 new provincial records for British Columbia (Polytrichum hyperboreum and Tayloria hornschuchii), one red-listed (threatened) species (Tortula systylia), and one blue-listed (at-risk) species (Mnium arizonicum). Polytrichum hyperboreum and T. hornschuchii have affinities to habitats more typical of polar regions. The presence of P. hyperboreum at Pink Mountain represents a southward range extension from $61^{\circ} 33^{\prime} \mathrm{N}$ in western North America. Because isolated populations at species distribution limits are likely to be vulnerable to climate change, the establishment of an ecological reserve on the south end of the summit of Pink Mountain is important for the preservation of bryophyte habitat.
\end{abstract}

Resumen.-La diversidad de briófitas en el norte de British Columbia ha sido poco estudiada. Nosotros realizamos un muestreo de briófitas en $2.2 \mathrm{~km}^{2}$ de la reserva ecológica que se encuentra en la cima de Pink Mountain en el distrito Peace River al norte de British Columbia. Pink Mountain se encuentra en la periferia sur del rasgo de distribución de varias especies de flora ártica, así como, en el rango de distribución más norteña de algunas especies de flora templada. La cima sur de Pink Mountain posee alta diversidad florística coincidente con la roca calcárea que forma el suelo, la cual proporciona condiciones más alcalinas para el crecimiento de las plantas que la cima norte. Documentamos 65 especies, incluyendo dos nuevos registros para la provincia de British Columbia Polytrichum hyperboreum y Tayloria hornschuchii, una de ellas se encuentra en la lista roja de especies amenazadas (Tortula systylia) y la otra en la lista azul de especies en riesgo (Mnium arizonicum). Polytrichum hyperboreum y T. hornschuchii tienen afinidad a los hábitats de las regiones polares. La presencia de P. hyperboreum en Pink Mountain representa una extensión hacia el sur en su rango de distribución de $61^{\circ} 33^{\prime} \mathrm{N}$ al oeste de Norteamérica. Debido a que, es probable que las poblaciones aisladas en los límites de distribución de las especies sean vulnerables al cambio climático, el establecimiento de una reserva ecológica en el extremo sur de la cima de Pink Mountain es de vital importancia para preservar el hábitat.

The Rocky Mountains of northern British Columbia are characterized by a mosaic of landscapes typical of montane regions of western North America. The bryophyte diversity of this region is poorly studied, even though it is distinctly different from that in the southern portions of the province or the near coastal mountains (Schofield 1988). For example, limited vouchers from the region have been deposited at the University of British Columbia Bryophyte Herbarium. Out of the 68,468 bryophyte vouchers with GPS data points deposited at the herbarium from different regions of British Columbia, only 7611 vouchers are from north of $54^{\circ} \mathrm{N}$, and only $2092(2 \%$ of the total) are from north of $54^{\circ} \mathrm{N}$ and east of $125^{\circ} \mathrm{W}$, which includes the Peace River region, an area of over $119,200 \mathrm{~km}^{2}$. This region represents $13 \%$ of the area of the province. Pink Mountain $\left(57^{\circ} 04.277^{\prime} \mathrm{N}, 122^{\circ} 52.484^{\prime} \mathrm{W}\right.$; Fig. 1) is an example of the Muskwa foothills ecosection located within the Peace River

*Corresponding author: rob.guy@ubc.ca 


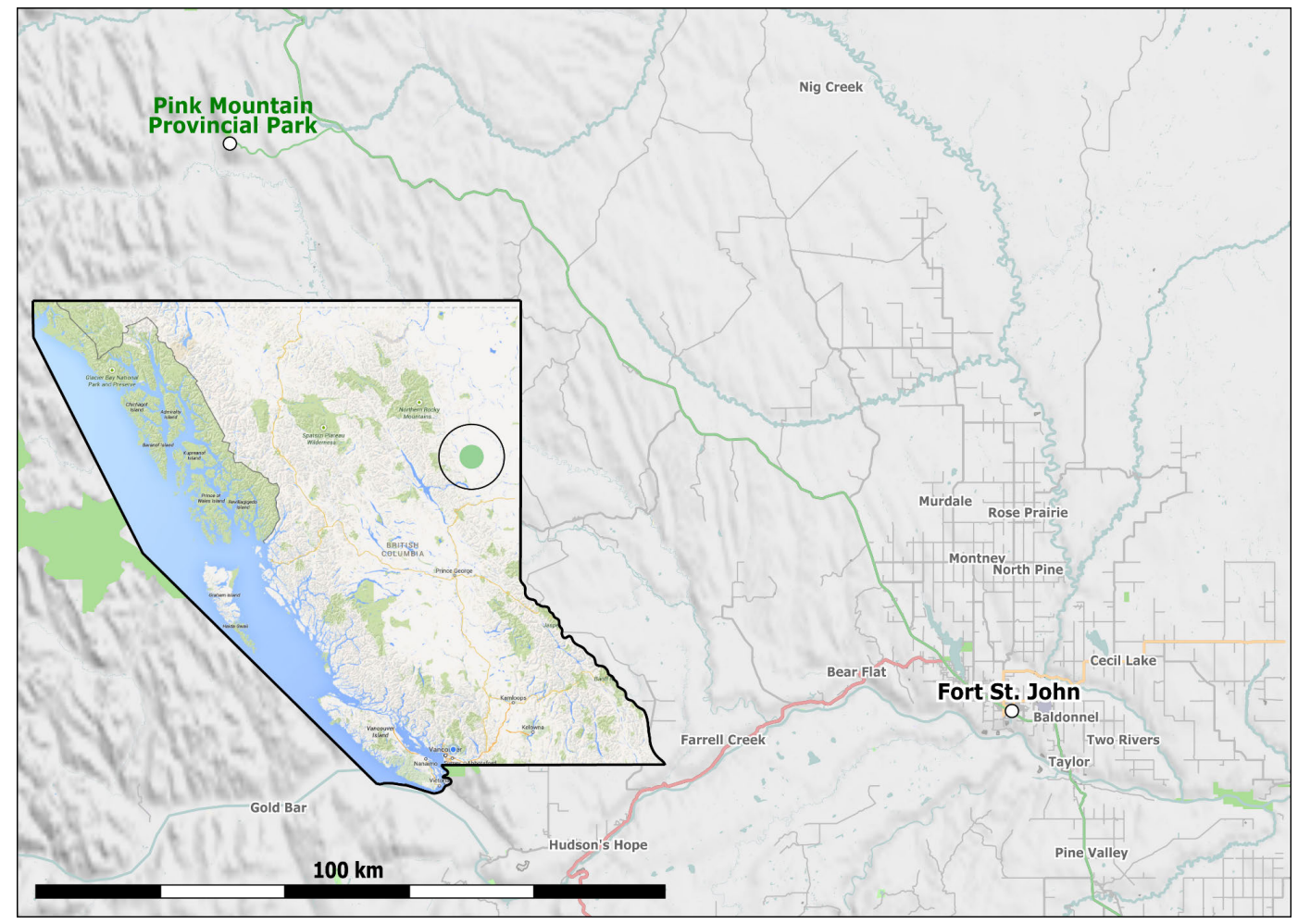

Fig. 1. Location map of Pink Mountain. Inset shows the location of Pink Mountain within the province of British Columbia.

region on the easternmost edge of the Northern Rocky Mountains. A comprehensive account of the bryophytes on Pink Mountain is lacking.

Pink Mountain is located within the SWBmk (Moist Cool Spruce-Willow-Birch) biogeoclimatic subzone with its valley bottoms dominated by white spruce (Picea glauca) and aspen (Populus tremuloides) (Pojar and Stewart 1991). These trees are replaced by subalpine fir (Abies lasiocarpa) and white spruce at higher elevations. The summit of the mountain, at $1770 \mathrm{~m}$, has a highly diverse arctic flora and fauna and is known for butterfly viewing. Its vegetation consists of a scrub subzone above the associated forest variant, with dwarf willows, grasses, sedges, forbs, and lichens. Pink Mountain Provincial Park, on the slopes west of the summit, was established to protect local fossil beds (Ackerman and Wilkin 2006). The climate of Pink Mountain is cool. According to Climate BC extrapolations based on 1961-1990 Climate Normals (Wang et al. 2016), the summit of Pink Mountain has a mean annual temperature of $-2.2{ }^{\circ} \mathrm{C}$ with 111 frost-free days, a mean warmest-month temperature of $9.5^{\circ} \mathrm{C}$, a mean coldest-month temperature of $-13.2{ }^{\circ} \mathrm{C}$, a mean annual precipitation of $749 \mathrm{~mm}$ (428 $\mathrm{mm}$ of the precipitation falls as snow), and an annual average relative humidity of $63 \%$.

Pink Mountain is of ecological interest because of its geological history, climatology, and location. Pink Mountain is at the southern periphery of the ranges of several arctic flora species, as well as the northernmost reaches of other temperate flora species. The south summit of Pink Mountain has an unusually high floristic diversity compared to the northern summit, and other peaks within the area, due to its limestone geology, which provides a more alkaline condition for plant growth. Pink Mountain hosts a plethora of microhabitats with different soil moisture and nutrient regimes to support a wide diversity of calcareous-associated species.

Pink Mountain took form as one of the asymmetrical folds parallel to the Rocky 
Mountain thrust belt. Due to the thrusting of the Rockies from west to east, "rippling" occurred at the front, thus forming the foothills, also known as the Laramide Orogeny, during the late Cretaceous (approximately 60 to 70 million years ago; Hinds and Spratt 2005). During the time of rippling, rocks from the Upper Cretaceous were the last rocks to be deposited and are most often exposed. As a result, almost all of the foothills in the area, including the northern summit of Pink Mountain, are covered by Middle or Lower Cretaceous rocks, which mainly consist of sandstone and shale. However, in some instances, where the ripple is sufficiently large and high, erosion has removed all the Cretaceous as well as some of the underlying Jurassic and Triassic rocks (Hinds and Spratt 2005). This is the case at the southern summit of Pink Mountain, where erosion has cut through into the Lower Triassic Montney Formation, which is now exposed at the summit. Triassic rocks in the area have considerable amounts of dolomite, limestone, phosphate (at the base of the Halfway River), halite (salts), and even shell beds (coquina) mixed in them (Hinds and Spratt 2005). Soil samples from the southern end of the summit have a high $\mathrm{pH}$, which indicates a parent rock of limestone and high plant nutrient levels (Long 2016). Bryophyte species assemblages on limestone formations are often very dissimilar from assemblages on other parent substrates (Hinds and Spratt 2005). Limestone-inhabiting bryophyte species tend to have higher calcium requirements and contents than bryophytes on nonbasic rock substrate.

Our objective was to survey and inventory the bryophyte flora in a proposed ecological reserve on the summit of Pink Mountain. Because limestone formations are known to have distinctive bryophyte species assemblages, we hypothesised that the southern summit of Pink Mountain may provide habitat for rare and disjunct calciphilic bryophytes that are unrepresented or underrepresented within British Columbia. This survey provides baseline information on the biodiversity of Pink Mountain for long-term conservation planning and resource management and improves knowledge of the bryophyte flora in arctic and alpine areas of the Peace River Region of British Columbia.

\section{Methods}

A bryophyte inventory of the proposed Pink Mountain Ecological Reserve was conducted over 4 days, 19-22 July 2014, at 19 collection sites within an area of approximately $2.2 \mathrm{~km}^{2}$ (Fig. 2). Specimens were collected using standard field collection techniques as described by Schofield and Drukker-Brammall (1992). The collection sites were identified based on geological features and chosen to encompass the variety of microhabitats on the mountain summit, with each site being a different side of a slope, a vale bottom, or a hilltop. All substrates within each of the collection sites (i.e., hummocks, ruts, rock faces, and crevices) were targeted for sampling, and field notes including the locality, microhabitat, substrate, and other environmental characteristics were recorded for all vouchers (refer to Table 1). Given the fragile ecosystem of the alpine meadows (see Supplementary Material 1 for photo), special care was taken to remove the smallest amount of material possible for each voucher. Care was also taken to avoid collecting the same species repeatedly to avoid overcollection. Additionally, the specimens were ranked on a qualitative abundance scale with 3 levels: scarce (observed only 1 time), occasional (observed 2-5 times), and common (observed $>5$ times).

The specimens were vouchered and deposited at the University of British Columbia (UBC) Herbarium (refer to Supplementary Material 2 for collection numbers). Occasionally voucher specimens consisted of more than one species mixed together. Moss identification, nomenclature, typical substrate associations, and arctic/alpine affinity were based on information in volumes 27 and 28 of Flora of North America (Flora of North America Bryophyte Editorial Committee 2015), supplemented by reference to Lawton (1971) and LaFarge-England and Vitt (1985). Liverwort identification and nomenclature were based on Söderström et al. (2016).

\section{Results}

The survey yielded a total of 65 species, 53 of which were collected (Table 2). Twenty-two of the collected species were scarce, 16 were occasional, and 15 were common on Pink Mountain. Eleven of the collected species 


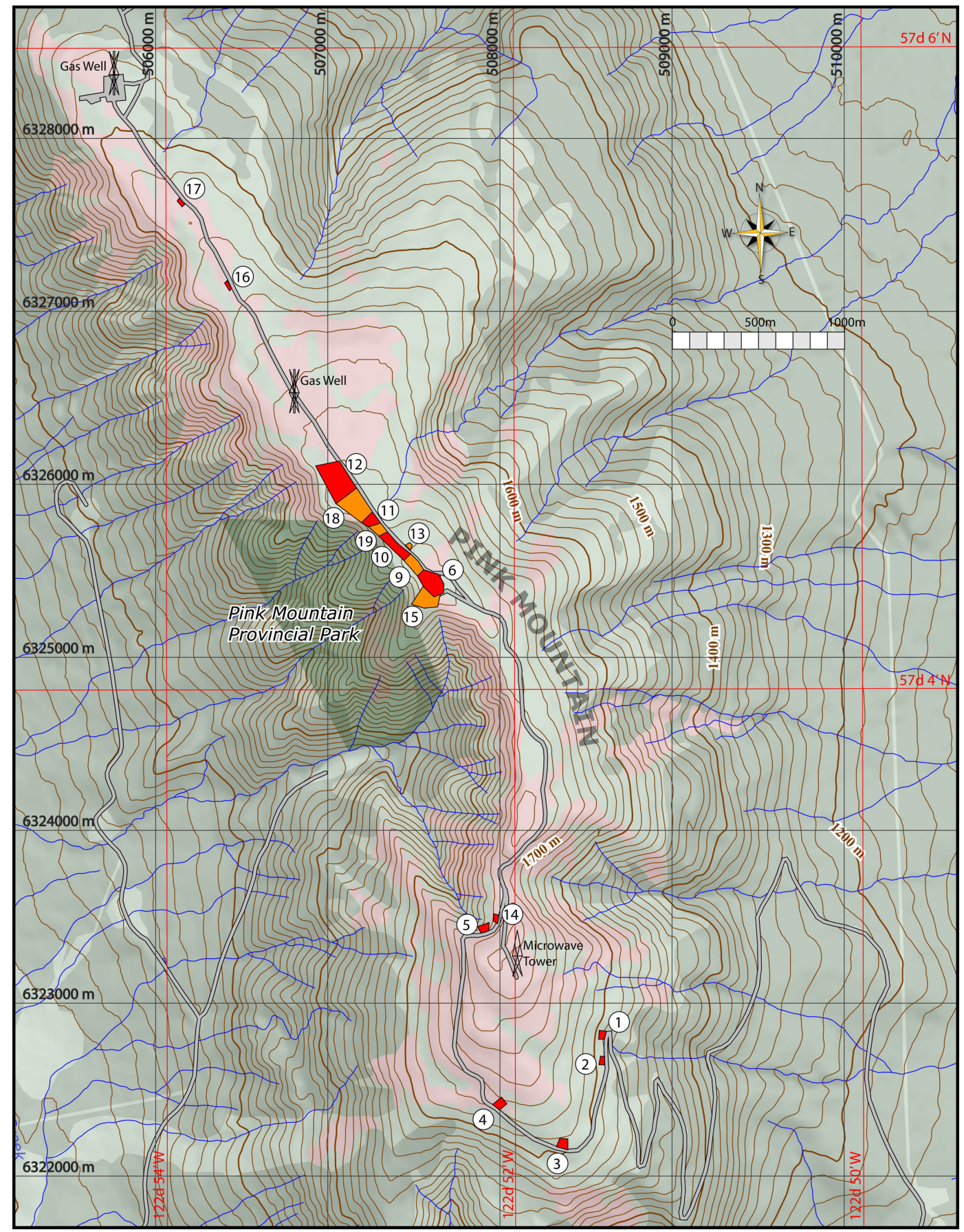

Fig. 2. Collection sites of the bryophyte inventory within the proposed ecological reserve on the summit of Pink Mountain, British Columbia. 
Wu et al. - Bryophytes of Pink Mountain, BC

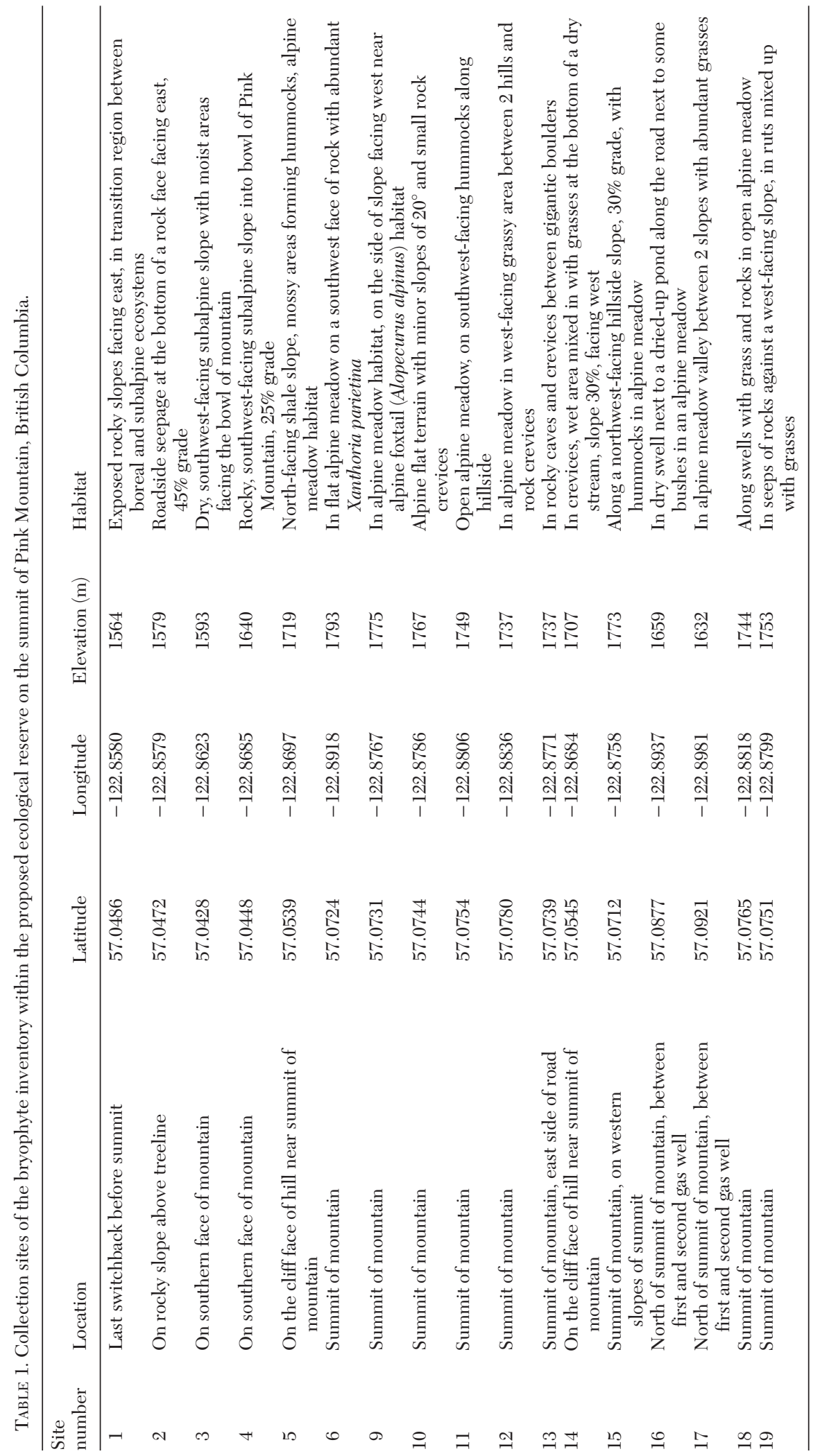


TABLE 2. Bryophyte species at Pink Mountain, British Columbia. Occurrences refer to site numbers where specimens were collected. Taxon abundance was measured on a scale of 3 rankings: scarce, occasional, and common (see methods for details). Notes specific to a taxon report, including reasons for uncertainty, are given below the table in footnotes. (See page 23 for continuation of Table 2 .)

\begin{tabular}{|c|c|c|c|}
\hline Taxon & Occurrence & Abundance & Notes \\
\hline Abietinella abietina (Hedw.) M. Fleischer & $12,14,15,19$ & occasional & \\
\hline Aulacomnium palustre (Hedw.) Schwägr. & $2,3,9,12,16,18,19$ & common & \\
\hline Aulacomnium turgidum (Wahlenb.) Schwägr. & $2,5,11,15,19$ & common & $!$ \\
\hline Barbilophozia hatcheri (A. Evans) Loeske & $1,9,10,13,14,18,19$ & common & \\
\hline Brachythecium coruscum I. Hagen & 16 & scarce & $!$ \\
\hline Brachythecium turgidum (Hartm.) Kinb. & 19 & scarce & \\
\hline Brachythecium creberrimum Taylor & 19 & scarce & \\
\hline Bryum pallens Sw. & 19 & scarce & * \\
\hline $\begin{array}{l}\text { Cephalozia bicuspidata ssp. ambigua (C. Massal.) } \\
\text { R.M. Schust. }\end{array}$ & 5 & scarce & \\
\hline Ceratodon purpureus (Hedw.) Brid. & 3,14 & occasional & $*$ \\
\hline Cynodontium strumiferum (Hedw.) Lindb. & 5,18 & scarce & \\
\hline Dicranum acutifolium (Lindb. \& Arnell) C.E.O. Jensen & $10,12,13,17,19$ & common & $*$ \\
\hline Dicranum cf. elongatum Schleich. ex Schwägr. & $9,11,12,13$ & common & A! \\
\hline Dicranum groenlandicum Brid. & $5,12,13,14,15$ & common & $!$ \\
\hline Dicranum spadiceum J.E. Zetterstedt & $1,9,12,15,16$ & common & \\
\hline Distichium capillaceum (Hedw.) Bruch \& Schimp. & 12,15 & occasional & \\
\hline Drepanocladus aduncus (Hedw.) Warnst. & 16,19 & occasional & \\
\hline Grimmia longirostris (Hook.) Ochyra \& arnowiec & 9,11 & occasional & \\
\hline Hylocomium splendens (Hedw.) Schimp. & $1,2,3,5,14,15,18,19$ & common & \\
\hline Hypnum cf. holmenii Ando & 15 & scarce & $\mathrm{B}^{*}$ \\
\hline Hypnum plicatulum (Lindb.) A. Jaeger & 5 & scarce & $!$ \\
\hline Hypnum revolutum (Mitt.) Lindb. & $9,11,12,13,14,16,19$ & common & $*$ \\
\hline Hypnum vaucheri Lesq. & 12 & scarce & $*$ \\
\hline Lophozia ventricosa (Dicks.) Dumort. & 2 & scarce & \\
\hline Mnium arizonicum J.J. Amann & 9 & scarce & 1 \\
\hline Orthotrichum anomalum Hedw. & 6,12 & occasional & $*$ \\
\hline Paraleucobryum enerve (Thed.) Loeske & 3,14 & occasional & \\
\hline Plagiomnium ellipticum (Brid.) T.J. Kop. & 19 & scarce & $!$ \\
\hline Pleurozium schreberi (Brid.) Mitt. & 1,18 & occasional & \\
\hline Pogonatum dentatum (Menzies ex Brid.) Brid. & 5 & scarce & \\
\hline Pohlia annotina (Hedw.) Lindb. & 14 & scarce & \\
\hline Pohlia bolanderi (Lesq.) Broth. & 14 & scarce & $!$ \\
\hline
\end{tabular}

were associated with calcareous substrate and 12 were associated with arctic or alpine habitats. The sites with the highest diversity appeared to be sites 19 (24 species), 12 (21 species), and 14 (16 species). Forty-one of the species collected were in the class Bryopsida, 7 in the class Polytrichopsida, and 5 in the class Jungermanniopsida. The bryophyte species composition of the summit ridge of Pink Mountain (sites $9,10,11,12,13,15,18$, and 19) is different from the lower alpine slopes of Pink Mountain (sites 1, 2, 3, 4, 5, and 14), and only about one-third of the species tallied occurred in both environments; the Bray-Curtis dissimilarity index (Bray and Curtis 1957) was 0.64. The collection yielded one provincial bluelisted (at-risk) species, Mnium arizonicum, and one provincial red-listed (threatened) species, Tortula systylia, as determined by the Conservation Data Center of British Columbia (B.C.
Conservation Data Centre 2017). Furthermore, there were 2 species new to British Columbia (Tayloria hornschuchii and Polytrichum hyperboreum), and both can be recommended for addition to the provincial red list. We found no other specimens of these 2 species from British Columbia in herbaria at UBC, the Royal British Columbia Museum, or the University of Alberta.

\section{Discussion}

This study documents the bryophyte flora on limestone formations in British Columbia. The south end of the summit of Pink Mountain provides a more alkaline substrate for calcareous species than the north end of the summit. In a comparison of soil attributes across different mountain peaks in the Muskwa Foothills ecosection (Long 2016), soil samples taken from the southern end of the summit 
TABLE 2. Continued.

\begin{tabular}{|c|c|c|c|}
\hline Taxon & Occurrence & Abundance & Notes \\
\hline Pohlia nutans (Hedw.) Lindb. & 5,12 & occasional & \\
\hline Polytrichastrum alpinum (Hedw.) G.L. Sm. & 14 & scarce & \\
\hline Polytrichum commune Hedw. & 2,17 & occasional & \\
\hline Polytrichum hyperboreum $\mathrm{R} . \mathrm{Br}$. & 12,16 & occasional & $2 !$ \\
\hline Polytrichum juniperinum Hedw. & $9,12,15,18$ & common & \\
\hline Polytrichum piliferum Hedw. & 9,12 & occasional & $!$ \\
\hline Polytrichum strictum Menzies ex Brid. & 17,19 & occasional & $!$ \\
\hline Ptilidium ciliare (L.) Hampe & $1,10,12,13,18,19$ & common & \\
\hline Ptychostomum subg. Claodium (Brid.) J.R. Spence & $1,12,16,19$ & occasional & \\
\hline Ptychostomum cryophilum (Mårtensson) J.R. Spence & 14 & scarce & \\
\hline $\begin{array}{l}\text { Ptychostomum pseudotriquetrum (Hedw.) J.R. Spence } \\
\text { \& H.P. Ramsay }\end{array}$ & $11,12,16,19$ & common & \\
\hline Racomitrium canescens (Hedw.) Brid. & $4,5,14$ & common & $*$ \\
\hline Rhytidium rugosum (Hedw.) Kindb. & $10,11,12,15,19$ & common & $*$ \\
\hline Sanionia uncinata $($ Hedw.) Loeske & $2,3,5,9,12,14,15,18,19$ & common & \\
\hline Solenostoma cf. confertissimum (Ness) Schljakov & 2 & scarce & $\mathrm{C}$ \\
\hline Syntrichia norvegica $\mathrm{F}$. Weber & $9,11,16,18$ & occasional & \\
\hline Syntrichia ruralis (Hedw.) F. Weber \& D. Mohr. & $12,14,15,19$ & occasional & \\
\hline Tayloria hornschuchii (Grev. \& Arn.) Broth. & 15 & scarce & $3 !$ \\
\hline Tomentypnum nitens (Hedw.) Loeske & 19 & scarce & $*$ \\
\hline Tortula systylia (Schimp.) Lindb. & 11 & scarce & $4 !^{*}$ \\
\hline Warnstorfia fluitans (Hedw.) Loeske & 19 & scarce & \\
\hline
\end{tabular}

Taxa observed but not vouchered

Anthelia juratzkana, Barbilophozia barbata, Brachythecium cf. erythrorrhizon, Didymodon sp., Encalypta sp. (sterile), Grimmia ovalis, Lophozia longidens, Orthotrichum speciosum, Pseudoleskea atricha, Ptilium crista-castrensis, Tortula hoppeana, Desmatodon latifolius

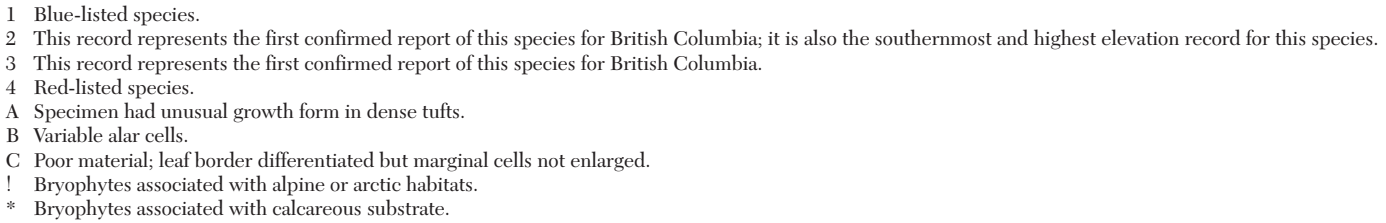

indicated a limestone parent material with a $\mathrm{pH}$ of 6.20 and consisted mostly of coarse sand with moderate amounts of organic matter. In contrast, a soil sample from the north end of the summit had a $\mathrm{pH}$ of 5.23 and consisted mostly of fine sand with minimal amounts of organic matter.

The bryophyte composition of Pink Mountain is distinctive, in accordance with its substrate diversity and location at a crossover zone between the southernmost distribution of arctic bryophyte species and the northernmost extent of other temperate species. The occurrence of Polytrichum hyperboreum at Pink Mountain represents a new species record for British Columbia and extends the known southern range limit of the species. We have not found any published records of $P$. hyperboreum south of $61^{\circ} 33^{\prime} \mathrm{N}$ in western North America. We propose changes to the key to Polytrichum species of British Columbia in order to add P. hyperboreum (Supplementary
Material 3). With the discovery of Tayloria hornschuchii in British Columbia, all 6 known Tayloria species in North America occur in the province (Flora of North America Bryophyte Editorial Committee 2015).

In the Northern Hemisphere, bryophyte populations at their southernmost species distribution limits are the most vulnerable to climate change, and their habitats should be conserved (Désamoré et al. 2012). The projection of expected species distributions into the future depends on the assumption that species preserve identical niche preferences and migrate to locations that remain suitable. The specific ecophysiological features of bryophytes make them especially good indicators of climate change (Désamoré et al. 2012). Particularly relevant features of mosses relative to climate change include poikilohydry and reliance on atmospheric precipitation for water as well as nutrient uptake, resulting in no net photosynthesis over prolonged periods of 
desiccation in patches (Bates et al. 2005); extreme sensitivity to moderate temperature increases in the temperate flora (Furness and Grime 1982); and effective dispersal ability. Consequently, changes in bryophyte communities are expected to result from major climatic shifts. For example, the extent of the changes in climate during the Holocene was enough to force bryophyte species to migrate in much the same manner as temperate tree species did (Svenning et al. 2008). Similar changes might be expected over the Anthropocene. Given the locally significant contribution of the expansive carpets of terrestrial bryophytes to the biomass of Pink Mountain, these changes can potentially pose severe functional consequences to the water storage, nutrient cycling, and microhabitat availability for other organisms in the alpine ecosystem.

Since the summit of Pink Mountain could be both the southernmost and highest elevation limit of certain arctic bryophyte species, it may be difficult for these populations to migrate if the climate of Pink Mountain becomes uninhabitable due to climate change. Rarity and lack of access to suitable habitat could limit dispersal of rarely fruiting dioicous species, such as Tayloria hornschuchii (LaFarge-England and Vitt 1985). Its known distribution within North America is primarily eastern Beringia, plus scattered locations in Alberta, Wyoming, and Colorado, and on Ellesmere Island (LaFargeEngland and Vitt 1985). The preferred substrate of Tayloria hornschuchii is humus or humic soil (LaFarge-England and Vitt 1985). Populations typically occur on exposed soil at the sides of erosional mini-mounds in tundra or polar semideserts. Such environments are common elsewhere within the northern Rocky Mountains; hence the absence of the species at other sites within the area would either indicate that the species has dispersal limitations preventing its establishment, or that the species is largely undercollected and more documentation is necessary. The same case can be made for other rare species found on Pink Mountain, such as Tortula systylia, which is a red-listed species with only one other known occurrence in British Columbia. Tortula systylia inhabits soils in rock crevices in high-elevation alpine tundra (Flora of North America Bryophyte Editorial Committee 2015).

Dispersal limitations and increased mortality at receding margins can result in extirpation of receding-edge populations and latitudinal displacement of the species range (Hampe and Petit 2005). In many bryophyte species, rearedge populations are typically smaller and more isolated and cannot easily compensate for local extinction events, so consequently the colonization front of long-distance dispersal events from larger lower-latitude populations becomes the dominating population dynamic (Hampe and Petit 2005). This dynamic also results in the observed poleward decrease in genetic diversity both within as well as among populations (Hewitt 2000). However, locally abundant moss species with large rear populations will likely have better long-term persistence and mitigating effects on range shifts and extinction. Stable rear-edge populations, because of their age, contain the bulk of the genetic diversity of species, and new adaptations are more likely to emerge from these regions (Hampe and Petit 2005). Although Polytrichum hyperboreum is at its southernmost and highest elevation extent at Pink Mountain, it is much more locally abundant than the other intrinsically rare bryophytes on Pink Mountain such as Tayloria hornschuchii, and could act as an important source population for dispersal to the north. Polytrichum hyperboreum normally occupies open stony or sandy ground, ridges, ravines, and tundra, and occurs in deep masses along lake margins and stream banks (Flora of North America Bryophyte Editorial Committee 2015). Retention of the population of $P$. hyperboreum, as well as other species with rear-edge populations on Pink Mountain, could potentially serve as a buffer to climate change.

\section{Conservation of Pink Mountain}

Pink Mountain provides habitat for many rare plants, including the bryophytes outlined in this study. Further study of this unique ecosystem including additional systematic survey of the bryophytes would likely contribute more species to the provincial checklist. In addition to the effects of climate change, Pink Mountain is at risk of several major environmental threats that could result in extensive habitat loss. Recreational visitors accessing the mountaintop by road for $4 \times 4$ off-roading can cause extensive damage to the mountain and disrupt the fragile alpine area. The reactivation of 2 existing gas wells that were established in the 1960s would result in increased industrial 
traffic and the bulldozing of large areas of tundra. The biggest threat is a proposal to install up to 40 wind turbines on the summit, whereby the concrete bases and expanded road network required to support these structures would severely impact the summit flora and fauna. The proposal to establish a $2.2-\mathrm{km}^{2}$ ecological reserve on the south end of the summit of Pink Mountain is important for the preservation of species habitat against such industrial development and for the mitigation of the loss of rare species because of climatic change.

\section{Supplementary Material}

Three online-only supplementary files accompany this article (scholarsarchive.byu .edu/wnan/vol78/issl/3).

Supplementary Material 1. Photograph of alpine tundra of the summit of Pink Mountain (21 July 2014).

Supplementary Material 2. Collection numbers for bryophyte voucher specimens deposited at the University of British Columbia (UBC) Herbarium.

Supplementary Material 3. Proposed key to Polytrichum of British Columbia (based on Flora of North America Bryophyte Editorial Committee 2007).

\section{ACKOWLEDGMENTS}

This project was made possible through the Pink Mountain Biodiversity Research Initiative. We thank Ron Long for his leadership in this initiative, Egan Davis for information on soil substrates, and Kees Viser for information about the geology of Pink Mountain. We also thank Steven Joya and Olivia Lee from the UBC Herbarium for their help with identification and curation of specimens.

\section{Literature Cited}

Ackerman, A., and N. Wilkin. 2006. Pink Mountain Provincial Park purpose statement and zoning plan. Integrated Land Management Bureau, BC Ministry of Agriculture and Lands. Victoria, BC, Canada.

Bates, J.W., K. Thompson, And J.P. Grime. 2005. Effects of simulated long-term climatic change on the bryophytes of a limestone grassland community. Global Change Biology 11:757-769.

B.C. Conservation Data Centre. 2017. BC Species and Ecosystems Explorer. BC Ministry of Environment, Victoria, BC; [accessed 3 May 2017]. http://a100 .gov.bc.ca/pub/eswp
Bray, J.R., AND J.T. Curtis. 1957. An ordination of the upland forest communities of southern Wisconsin. Ecological Monographs 27:325-349.

Désamoré, A., B. Laenen, M. Stech, B. Papp, L. Hedenäs, R.G. Mateo, and A. Vanderpoorten. 2012. How do temperate bryophytes face the challenge of a changing environment? Lessons from the past and predictions for the future. Global Change Biology 18:2915-2924.

Flora of North America Bryophyte Editorial CommitTEE. 2015. Flora of North America [North of Mexico]. Volumes 27-28. Oxford University Press, New York, NY.

Furness, S.B., AND J.P. GRIme. 1982. Growth rate and temperature responses in bryophytes: II. A comparative study of species of contrasted ecology. Journal of Ecology 70:525-536.

Hampe, A., AND R.J. Petit. 2005. Conserving biodiversity under climate change: the rear edge matters. Ecology Letters 8:461-467.

HewitT, G. 2000. The genetic legacy of the Quaternary ice ages. Nature 405:907-913.

Hinds, S.J., AND D.A. SpratT. 2005. Stratigraphy, structure and tectonic history of the Pink Mountain Anticline, Trutch (94G) and Halfway River (94B) map areas, northeastern British Columbia. Bulletin of Canadian Petroleum Geology 53:84-98.

LaFarge-England, C., AND D.H. VitT. 1985. A taxonomic study of Tayloria hornschuchii and T. froelichiana in North America. Bryologist 88:82-93.

Lawton, E. 1971. Moss flora of the Pacific Northwest. Hattori Botanical Laboratory, Nichinan, Japan. 362 pp.

Long, R. 2016. The unique biodiversity of Pink Mountain. Unpublished report for BC Ministry of Forests, Lands and Natural Resource Operations.

POJAR, J., AND A.C. STEWART. 1991. Spruce-willow-birch zone. Pages 251-262 in D. Meidinger and J. Pojar, editors, Ecosystems of British Columbia. Research Branch, BC Ministry of Forests, Victoria, BC Special Report Series, no. 6.

SCHOFIELD, W.B. 1988. Bryogeography and the bryophytic characterization of biogeoclimatic zones of British Columbia, Canada. Canadian Journal of Botany 66:2673-2686.

Schofield, W.B., and P. Drukker-Brammall. 1992. Some common mosses of British Columbia. Royal British Columbia Museum, Victoria, BC, Canada.

Söderström, L., A. Hagborg, M. von Konrat, S. BarTholomew-Began, D. Bell, L. Briscoe, E. Brown, D.C. Cargill, D.P. Costa, B.J. Crandall-Stotler, ET AL. 2016. World checklist of hornworts and liverworts. PhytoKeys 59:1-828.

Svenning, J.C., S. Normand, and M. Kageyama. 2008. Glacial refugia of temperate trees in Europe: insights from species distribution modeling. Journal of Ecology 96:1117-1127.

Wang, T., A. Hamann, D. Spittlehouse, and C. Carroll. 2016. Locally downscaled and spatially customizable climate data for historical and future periods for North America. PLOS ONE 11(6):e0156720.

Received 7 June 2017 Revised 10 November 2017 Accepted 13 November 2017 Published online 12 April 2018 